\title{
First report of Golovinomyces cichoracearum associated with powdery mildew on Helianthus tuberosus in Korea
}

\author{
Sung-Eun Cho • Mi-Jeong Park • Ji-Hyun Park • \\ Kyung-Sook Han $\cdot$ Hyeon-Dong Shin
}

Received: 28 July 2011 / Accepted: 10 January 2012 / Published online: 1 February 2012

(C) Australasian Plant Pathology Society Inc. 2012

\begin{abstract}
Helianthus tuberosus has been found to be infected with a powdery mildew fungus in Korea since 2000. The fungus was identified as Golovinomyces cichoracearum based on the morphological characteristics of the anamorph and ITS sequence analysis. This is the first record of HelianthusGolovinomyces association in Korea.
\end{abstract}

Keywords Golovinomyces cichoracearum $\cdot$ Helianthus tuberosus $\cdot$ ITS sequence $\cdot$ Jerusalem artichoke $\cdot$ Powdery mildew

Helianthus tuberosus L., commonly called Jerusalem artichoke, is a herbaceous perennial plant, belonging to the tribe Heliantheae of the family Asteraceae. It is native to North America and was introduced to Korea in the late 19th century (Park 2009). The plant has been cultivated partly for commercial purpose, but mostly for self-consumption in the family hobby gardens. It is now widely naturalized and commonly found growing wild, disturbing native plant communities, in Korea.

During extensive surveys of plant pathogens conducted on naturalized exotic plants in Korea between 2000 and 2010 , typical symptoms of a powdery mildew disease were frequently observed on $\mathrm{H}$. tuberosus in various localities of

\section{S.-E. Cho $\cdot$ M.-J. Park $\cdot$ J.-H. Park $\cdot$ H.-D. Shin $(\triangle)$}

Division of Environmental Science and Ecological Engineering, College of Life Sciences and Biotechnology, Korea University, Seoul 136-701, Korea

e-mail: hdshin@korea.ac.kr

K.-S. Han

Horticultural \& Herbal Environment Division,

National Institute of Horticultural \& Herbal Science,

Rural Development Administration,

Suwon 441-440, Korea
Korea. Symptoms included extensive cover of the plant by white patches of external superficial mycelia with abundant conidiophores and conidia (Fig. 1a-b). Infections of young shoots were also commonly found, sometimes resulting in drying or dying of the shoots (Fig. 1a). These symptoms were mainly observed in September and October when the plants usually show a decline in vigour. No chasmothecia formation was observed until the shoots and leaves senesced and died in November and December. 18 voucher specimens were deposited in the herbarium of Korea University (KUS) in Seoul, Korea. Preliminary examinations of these materials showed that infections are always associated with an Oidium subgenus Reticuloidium, which is an anamorphic state of the genus Golovinomyces (Cook et al. 1997).

For identification of the causal agent, fungal structures were detached from the powdery mildew colonies on fresh leaves. Each structure was examined in bright field- and differential interference contrast (DIC)-light microscopy. At least 20 measurements were made for each structure. The mycological description was based on a representative sample (KUS-F25492, Seoul, October 2010, leg. H.D. Shin).

Mycelia on both sides of leaves and also on stems were sub-persistent to sub-evanescent, forming circular to irregular white patches or covering the whole surface with thin layer of mycelium (Fig. 1a-b). Hyphae were sub-straight to wavy, occasionally geniculate, $40-80 \mu \mathrm{m}$ long, 4-7 $\mu \mathrm{m}$ wide, mostly branching at a right angle, with a septum near the branching point. Hyphal appressoria were poorly developed, nipple-shaped, and single. Conidiophores were single on a hyphal cell, arising from the upper part of mother cells, producing 2-4 swollen cells in chains with a sinuate outline, 120-220 $\mu \mathrm{m}$ long; foot-cells straight, $65-120 \times 9-12 \mu \mathrm{m}$, simple, with a basal septum at the branching point or slightly displaced from the mycelium (Fig. 1c-e). Conidia were 
Fig. 1 Powdery mildew infections of Helianthus tuberosus by Golovinomyces cichoracearum. a Infections of young shoots. b Colonies formed on a leaf. $\mathbf{c}-\mathbf{e}$ Conidiophores. f Conidia. $\mathbf{g}$ Reticulate network of the conidium surface viewed with DIC microscopy. Bar $=30 \mu \mathrm{m}$ for $\mathbf{c}-\mathbf{f}$ and $10 \mu \mathrm{m}$ for $\mathbf{g}$
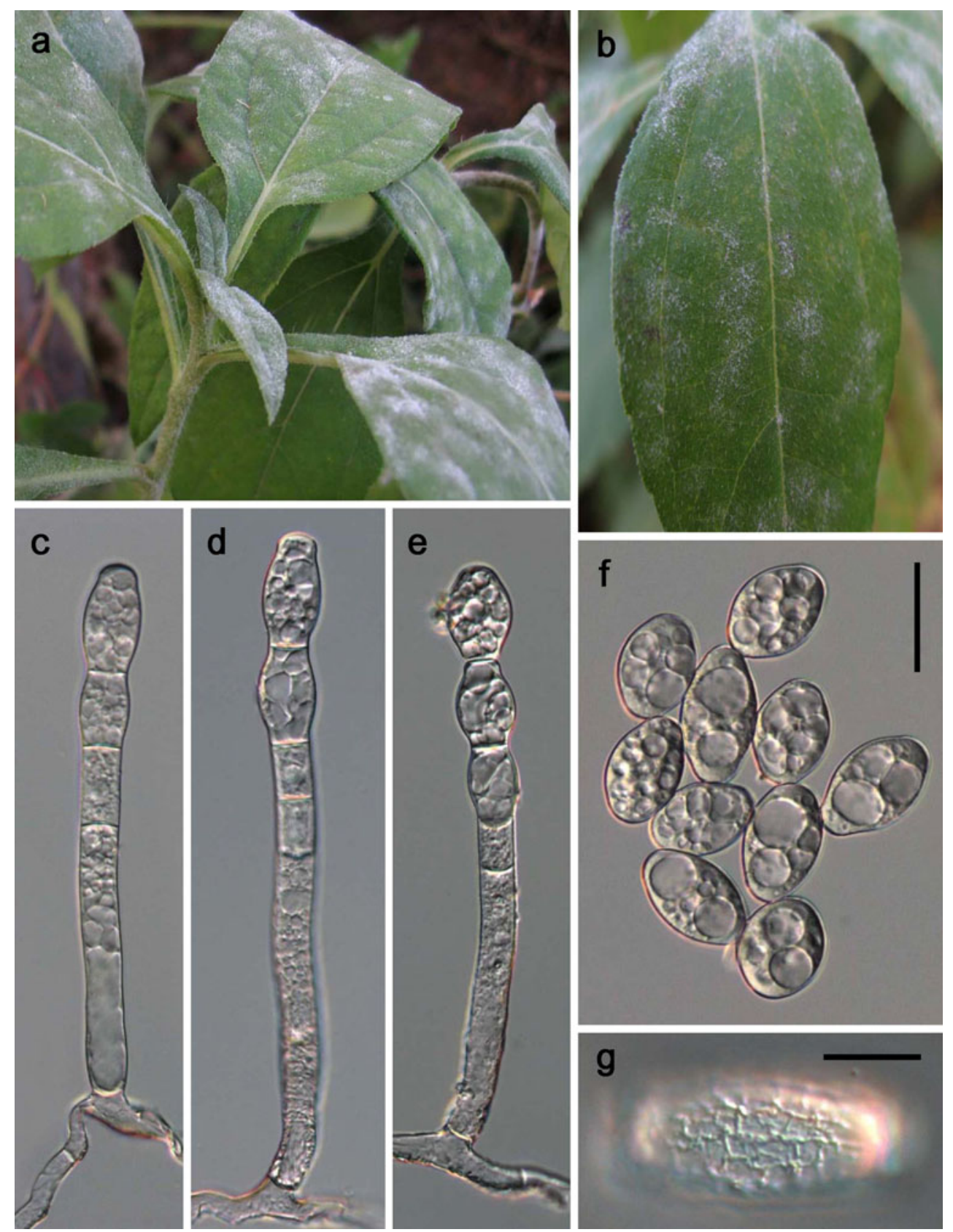

oval to ellipsoid, $30-42 \times 20-26 \mu \mathrm{m}$ (length/breadth ratio $=1.3-$ 1.9), lacking distinct fibrosin bodies, producing germ tubes on the perihilar position, with reticulate wrinkling of the outer walls (Fig. 1f-g). First-formed conidia were apically conical, basally round to more or less subtruncate, and generally shorter (30-36 $\mu \mathrm{m}$ long) than the secondary conidia. Based on these morphological measurements, this fungus was compatible with Golovinomyces cichoracearum (DC.) V.P. Heluta described previously (Braun 1987; Nomura 1997; Shin 2000).

To confirm the identification based on morphological characteristics, molecular analysis of internal transcribed spacer (ITS) rDNA sequence from a representative sample
(KUS-F25492) was done. The complete ITS region of rDNA was amplified with primers ITS5 and P3 as described by Takamatsu et al. (2009), and directly sequenced. The resulting sequence of 508 bp was deposited in GenBank (acc. no. JN384115). A GenBank BLAST search with the present data showed over $99 \%$ similarity with the ITS sequences of $G$. cichoracearum ex host plants belonging to the tribe Heliantheae (family Asteraceae); e.g. AB000934 (ex Eupatorium japonicum), AB077622 (ex Rudbeckia laciniata), AF011292 (ex Ambrosia trifida), AY739110 (ex Helianthus annuus), GQ183949 (ex Dahlia sp.), and HQ214032 (ex Zinnia elegans). Therefore, the sequence analysis verified the pathogen to be G. cichoracearum. 
Though angular leaf spot disease associated with foliar nematode (Aphelenchoides fragariae) was recorded (Khan et al. 2007), no other diseases have been known on this plant (The Korean Society of Plant Pathology 2009). Powdery mildew is the first fungal disease on $H$. tuberosus in Korea. Powdery mildew infections of $H$. tuberosus with G. cichoracearum complex (including G. cichoracearum var. latisporus and G. ambrosiae) have been recorded from nearly all European countries, North America and Argentina (Farr and Rossman 2011), and also recently from Japan (Hoshi et al. 2007). This is the first report of G. cichoracearum on H. tuberosus in Korea.

\section{References}

Braun U (1987) A monograph of the Erysiphales (Powdery Mildews). Beih Nova Hedw 89:1-700

Cook RTA, Inman AJ, Billings C (1997) Identification and classification of powdery mildew anamorphs using light and scanning electron microscopy and host range data. Mycol Res 101:9751002. doi:10.1017/S095375629700364X

Farr DF, Rossman AY (2011) Fungal databases, systematic mycology and microbiology laboratory, ARS, USDA. Retrieved 25th July 2011, from http://nt.ars-grin.gov/fungaldatabases/

Hoshi H, Sato Y, Horie H (2007) Occurrence of zinnia and Jerusalem artichoke powdery mildew by Oidium subgenus Reticuloidium, and host range of the subgenus of powdery mildew on several plants species occurred at Tokyo. Ann Phytopathol Soc Japan 73:182, abstract

Khan Z, Son SH, Moon HS, Kim SG, Shin HD, Kim YH (2007) The foliar nematode, Aphelenchoides fragariae, on Jerusalem artichoke (Helianthus tuberosus) and weigela (Weigela subsessilis). Nematropica 37:335-337

Nomura Y (1997) Taxonomical study of Erysiphaceae of Japan. Yokendo Ltd, Tokyo, p 281

Park SH (2009) New illustrations and photographs of naturalized plants of Korea. Ilchokak Publisher, Seoul, p 575

Shin HD (2000) Erysiphaceae of Korea. National Institute of Agricultural Science \& Technology, Suwon, p 320

Takamatsu S, Heluta V, Havrylenko M, Divarangkoon R (2009) Four powdery mildew species with catenate conidia infect Galium: molecular and morphological evidence. Mycol Res 113:117129. doi:10.1016/j.mycres.2008.09.006

The Korean Society of Plant Pathology (2009) List of plant diseases in Korea, 5th ed. Suwon, Korea, p 853 